\title{
Assessment of Energy Consumption Pattern and Energy Conservation Potential at Indian Airports
}

\author{
Kanika Malik
}

\begin{abstract}
Published online: 24 November 2017
To cite this article: Kanika Malik. (2017). Assessment of energy consumption pattern and energy conservation potential at Indian airports. Journal of Construction in Developing Countries, 22(Supp. 1): 97-119. https://doi.org/10.21315/jcdc2017.22. supp 1.6

To link to this article: https://doi.org/10.21315/jcdc2017.22.suppl.6
\end{abstract}

\begin{abstract}
With the growing energy crisis, the need to conserve and manage energy resources in a responsible manner is being increasingly felt by different sectors of the economy. India's civil aviation industry is on a high-growth trajectory. India aims to become the third-largest aviation market by 2020 and the largest by 2030. The rise in the energy needs of airports to satisfy this demand has led to great concerns about the environmental impact of the aviation industry. Long term sustainability of airports is getting more important in this scenario. As demand for air travel continues to grow, aviation's environmental impacts need to be addressed while continuing to maximize its social and economic benefits. This paper presents the problem of high energy consumption in the aviation sector by analysing the energy consumption data of three Indian airports in the composite climatic zone of India and the imperative need to design energy efficient airports. Data was collected from energy audits, which were conducted over a period of one year. The collected information was used to perform an analysis for assessing specific measures to reduce energy use at the passenger terminal building (PTB) and to identify possible actions for improving the airport performance.
\end{abstract}

Keywords: Airports, Energy audits, Passenger terminal buildings, Energy consumption, Energy conservation

\section{INTRODUCTION}

Airports are big energy consumers, and that's before a plane takes off and lands. The daily energy used by a large airport compares to that of a city of 100,000 people (Maximilian, 2014). Airports are amongst the most energy intensive centres in modern society (Edwards, 2005).

Airport terminals are major transportation facilities. These types of buildings have very distinct operational and architectural characteristics (Balaras et al., 2003). Usually, major airports in India operate on a $24 \mathrm{~h}$ basis throughout the year, with variable schedules and occupancy during certain periods. Energy and efforts to reduce consumption are becoming significant environmental factors in many Indian airports, while trying to address sustainability issues.

The aviation industry has chartered unprecedented growth in the 21st century. The potential for further growth in terms of passenger traffic is massive given that only around $1 \%$ of the population has ever flown (Upham et al., 2003). While augmenting economic growth in a significant way, the industry is accountable for contributing to environmental controversies like fuel and energy consumption, emission issues, and global warming. The impact is also enhanced by the changing

Deenbandhu Chhotu Ram University of Science and Technology, INDIA

Corresponding author: kanikamalik7@gmail.com 
concept of an airport from a simple aerodrome to one of an airport city (Babu, 2008). Figure 1 shows the illustrative airport environmental footprint. The construction and operation of an airport like any other land use development can have a wide variety of effects. Some of these effects are desirable and some are undesirable such as air pollution in the form of aircraft emissions, vehicle emissions, indoor air contamination and water pollution such as waste water discharge, groundwater contamination due to construction activities, and high energy consumption both on the airside and landside of the airport. Out of all the parameters mentioned, the focus in this paper would be on energy consumption of the passenger terminal building (PTB).

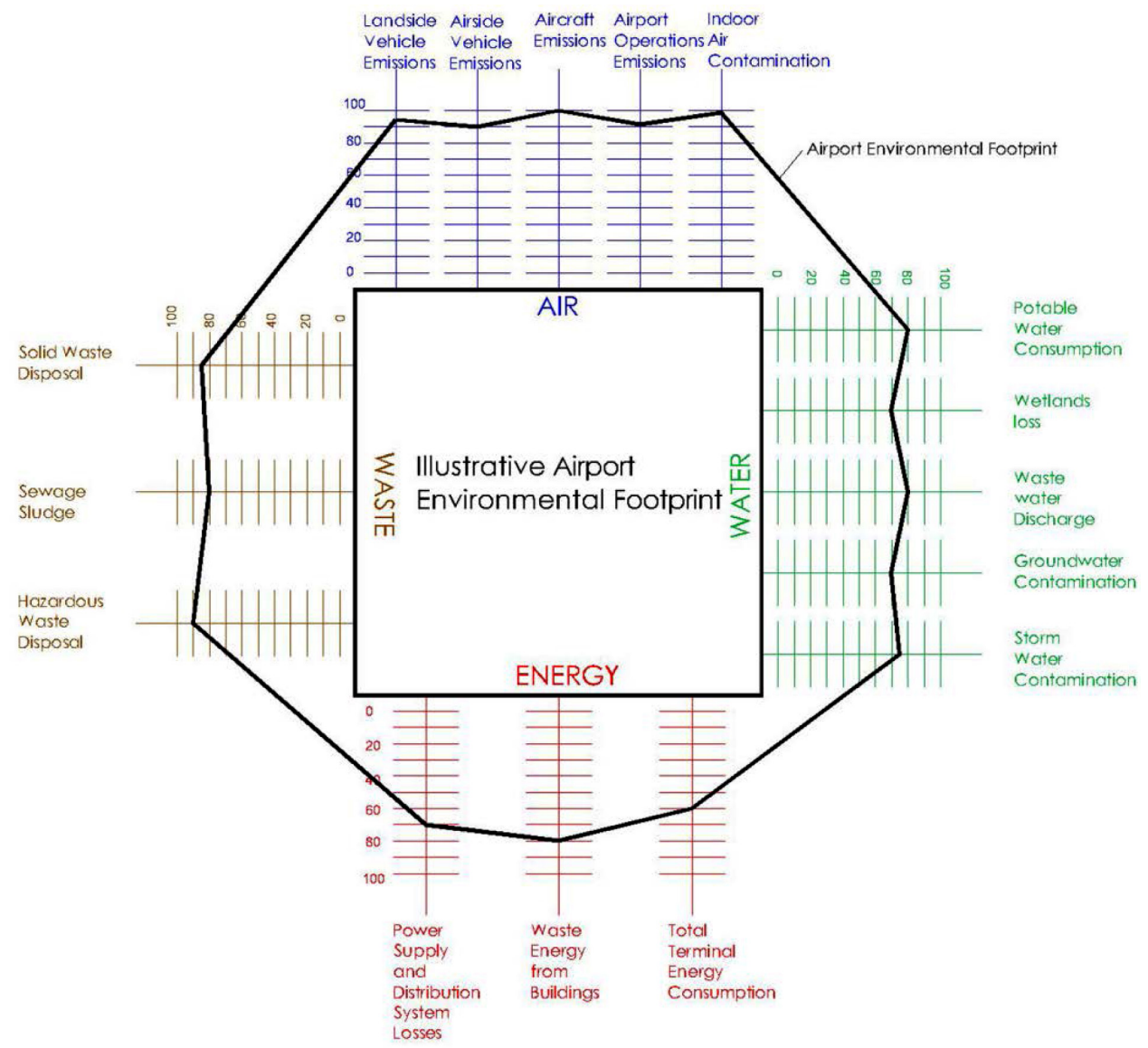

Figure 1. Illustrative Airport Environmental Footprint

\section{Indian Context}

India's civil aviation industry is on a high-growth trajectory. India is the ninth-largest civil aviation market in the world, with a market size of around US\$ 16 billion. India is among the five fastest-growing aviation markets globally with 275 million new 
passengers (India Brand Equity Foundation [IBEF], 2016). India aims to become the third-largest aviation market by 2020 and the largest by 2030 . The civil aviation industry has ushered in a new era of expansion, driven by factors such as low-cost carriers (LCCS), modern airports, Foreign Direct Investment (FDI) in domestic airlines, advanced information technology (IT) interventions, and growing emphasis on regional connectivity (IBEF, 2016). India's domestic traffic is fourth after US, China, and Japan (International Air Transport Association [IATA], 2013).

In January 2016, domestic air passenger traffic rose $23 \%$ to 7.66 million from 6.25 million during the same month of last year. Passenger traffic during the JanuaryDecember 2015 increased at a rate of $20.3 \%$ to 81.1 million from 67.4 million in the corresponding period a year ago (IBEF, 2016). Indian domestic air traffic is expected to cross 100 million passengers by FY2017, compared to 81 million passengers in 2015, as per Centre for Asia Pacific Aviation (CAPA). In January 2016, total aircraft movements at all Indian airports stood at 156,048, which was $15.9 \%$ higher than January 2015. International and domestic aircraft movements increased $10.6 \%$ and $17.5 \%$, respectively, in January 2016 (IBEF, 2016). Passenger terminal capacity in all airports put together is expected to be 230-240 million by 2012 and by 2017 it would be about 370 million as per the investment plans of the operators. The complete fleet size is expected to grow from about 400 to 1000 aircraft by 2020 . Rs. 65,000 crore has been earmarked for the airport sector in the 12th five-year plan by the Government of India.

Indian aviation industry promises huge growth potential due to large and growing middle class population, rapid economic growth, higher disposable incomes, rising aspirations of the middle class, and overall low penetration levels (Malviya and Shah, 2015).

The government of India has planned to develop about 200 new low cost airports in the next 20 years, to connect Tier-II and Tier-III cities, in order to meet the surge in demand due to other nationwide developmental activities. Tier-II cities are the ones which have a population ranging between 50,000 to 99,999 such as Raipur and Aurangabad and Tier-III cities have population ranging between 20,000 to 49,999 such as Udaipur. The low-cost airport's model will be based on smaller size airports with modular concept having all the basic and essential infrastructure thereby reducing the overall operating and service cost of operations for the airports. The low-cost airport model, however, will not compromise on the technical, security, and other issues related to essential services at airports.

Airports are large scale infrastructure projects with long term impact. However, infrastructure and facilities provided at Indian airports have not been able to keep pace with this growth, leading to poor quality of space available for operations. In most cases, this is coupled with poor ambience and poor comfort conditions leading to an unsatisfactory visual appeal and passenger experience. There is a heavy dependence on artificial lights and air conditioning in India. In most of the existing airports, the potential for daylighting and natural ventilation has not been explored adequately (Babu, 2008).

Airport terminal buildings consist of large, open plan areas, often with high ceilings, ticketing counters, waiting areas, small office spaces, and various types of stores, concessions, and convenience facilities. Internal loads are primarily due to people, with substantially variable occupancy, while lighting and equipment loads are generally average (American Society of Heating, Refrigerating and AirConditioning Engineers [ASHRAE], 2003). External loads vary depending on the architecture of the building, although solar gains are usually high because of the 
large external glazing. Central heating and cooling with all-air systems are preferred (Balaras et al., 2003). This leads to an energy intensive nature of the PTB. Thus, the need to address the same assumes paramount importance in the wake of the overall energy crisis that India is facing (Babu, 2008).

\section{ENERGY CONSERVATION}

The potential for energy conservation depends on the specific characteristics of each facility. In general, the following priorities apply: (a) reduce heating and cooling loads; (b) exploit passive solar heating systems and techniques during winter and passive and hybrid cooling during summer; (c) exploit day lighting; (d) select, install, operate, and maintain properly all the mechanical and electrical systems and components; (e) control the operation of all installations to optimise energy consumption while maintaining the appropriate indoor environmental quality (Balaras et al., 2003).

Possible interventions and available options depend on the existing installations in the facility according to the: (a) quality of the original construction and existing installations; (b) program of operation; (c) existing condition of the building envelope; (d) existing condition of the installations for heating, cooling, and lighting, and the general intervention opportunities. Each facility has specific characteristics and all possible interventions must be first evaluated for the given facility. One has to start by identifying all the opportunities to reduce energy consumption with the lowest cost. In many cases, this can be achieved by simple house-keeping. Additional energy conservation measures must be carefully evaluated and substantiated in relation to their payback period. The money saved from the initial measures can then be invested to finance future, more demanding interventions (Balaras et al., 2003).

To optimise the effectiveness of an energy conservation campaign, it is necessary to secure the collaboration of all employees and not just the technical (i.e. operations and maintenance) staff, which is common practice. Employee involvement along with upgraded building facilities and electrical/mechanical installations, and the use of central automated control systems, can achieve proper energy use and improve indoor conditions in the working and public access areas. Building management systems (BMS) can be used to control heating, ventilation, and air conditioning (HVAC) equipment, lighting and power management, in addition to other airport operations, in order to optimise indoor comfort conditions and reduce energy consumption (Ancevic, 1997). Proper staff training has been demonstrated to reduce energy costs through improved operating strategies and control, while improving service quality, occupant comfort, and service reliability (Manczyk, 2000).

\section{Objective of the Study}

Airport processes centres around aircrafts, passengers, and cargo with these processes overlapping mostly. Handling of these essential components is rendered efficiently through a host of support functions, which make the processes comfortable, convenient, and safe. Several utilities are deployed to make this possible. 
Given the fact that the PTB has high levels of energy consumption compared to other buildings at the airport, an assessment of the energy consumption pattern at the terminal buildings of three airports in India has been undertaken (Babu, 2008). It is the largest energy consumer because of its function as a node for processing passengers and cargo and the large number of facilities required for its operation. This study will help to analyse which areas in a terminal building consume maximum energy and thereby have scope for improvement.

\section{METHODOLOGY}

India has more than 476 airports that include abandoned and disused airports and aerodromes. Airports Authority of India (AAI) owns and maintains 125 airports comprising 95 operational airports and 30 non-operational airports with no scheduled flights. Out of these airports energy audits have been conducted at 42 airports in the year 2015-2016 and 14 more airports are being taken up for energy audit in the year 2016-2017.

For studying the energy consumption pattern at Indian Airports the energy audits of three airports were studied extensively. During the study, building and energy related data was collected from three Indian airports namely Raipur, Aurangabad, and Udaipur, in an effort to document the existing condition and make a preliminary assessment for the energy conservation potential at airports in India. The location of the airports is shown in Figure 2.

As per National Building Code of India (NBC), India is divided into five climatic zones:

1. Hot-dry

2. Warm-humid

3. Composite

4. Temperate

5. Cold

Major part of the country falls in the composite climatic zone. The three selected airports fall in the composite climatic zone and have similar climatic conditions as illustrated in Table 1. Due to the geographical location of the airports and since their terminal buildings are similar in size their energy consumption patterns are comparable. The Table 2 provides the statistics related to passenger movement, aircraft movement, and cargo movement with respect to these three airports for the year 2014-2015.

The scope of the audits was restricted to the terminal building. This study involved performance assessment of the key energy consuming equipment such as HVAC, lighting, and all major electrical motors and to subsequently establish margins for improvement. The baseline data was collected from August 2014 to July 2015. All calculations for this paper are done based on the data provided by AAl, the necessary measurements taken during the study, and the operating conditions prevailing during the study period. The study of the energy audits at the airports was done to review the present energy consumption scenario, monitoring and analysis of the use of energy, monitoring of the equipment performance with regard to its efficiency level, and explore the energy conservation opportunities at the three airports. The scope covers electrical distribution system, harmonic analysis, location 
wise load details, lighting system, HVAC system, and cost benefit analysis of each energy conservation opportunities (ENCON).

To get this information, preliminary visit to each of the sub-systems, to obtain an overview were conducted. To collect the relevant data, forms/checklists were prepared and were followed by discussions with concerned executives.

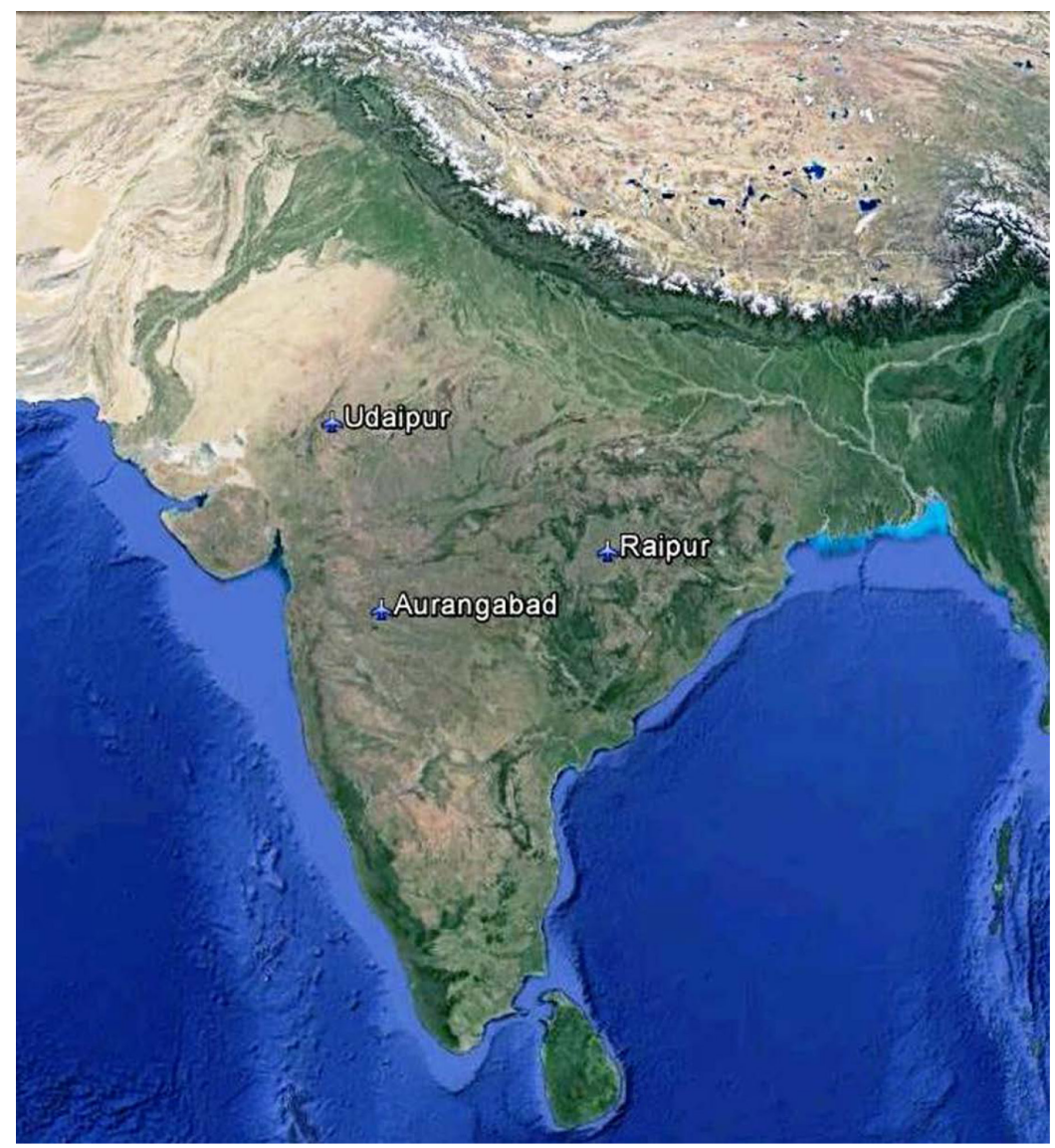

Figure 2. Location of the Airports Source: Google Earth (12/14/2015)

Measurements were taken with the help of diagnostic portable instruments for power measurement such as a power analyser, flow meter used for water flow measurement, and Digital Lux meter used for checking the level of luminance. Infra-red and conventional temperature measurement instruments such as a temperature data logger were used that are capable of autonomously recording temperature over a defined period of time. The digital data was retrieved, viewed, and evaluated after it had been recorded. Digital thermo hygrometer was used for measuring the moisture content in the atmosphere and digital anemometer for measuring the speed of wind. Field studies were carried out in each of the subsystems without disturbing normal operation of working equipment. 
Table 1. Geographical Information and Monthly Mean Maximum and Minimum Temperature of Analysed Airports

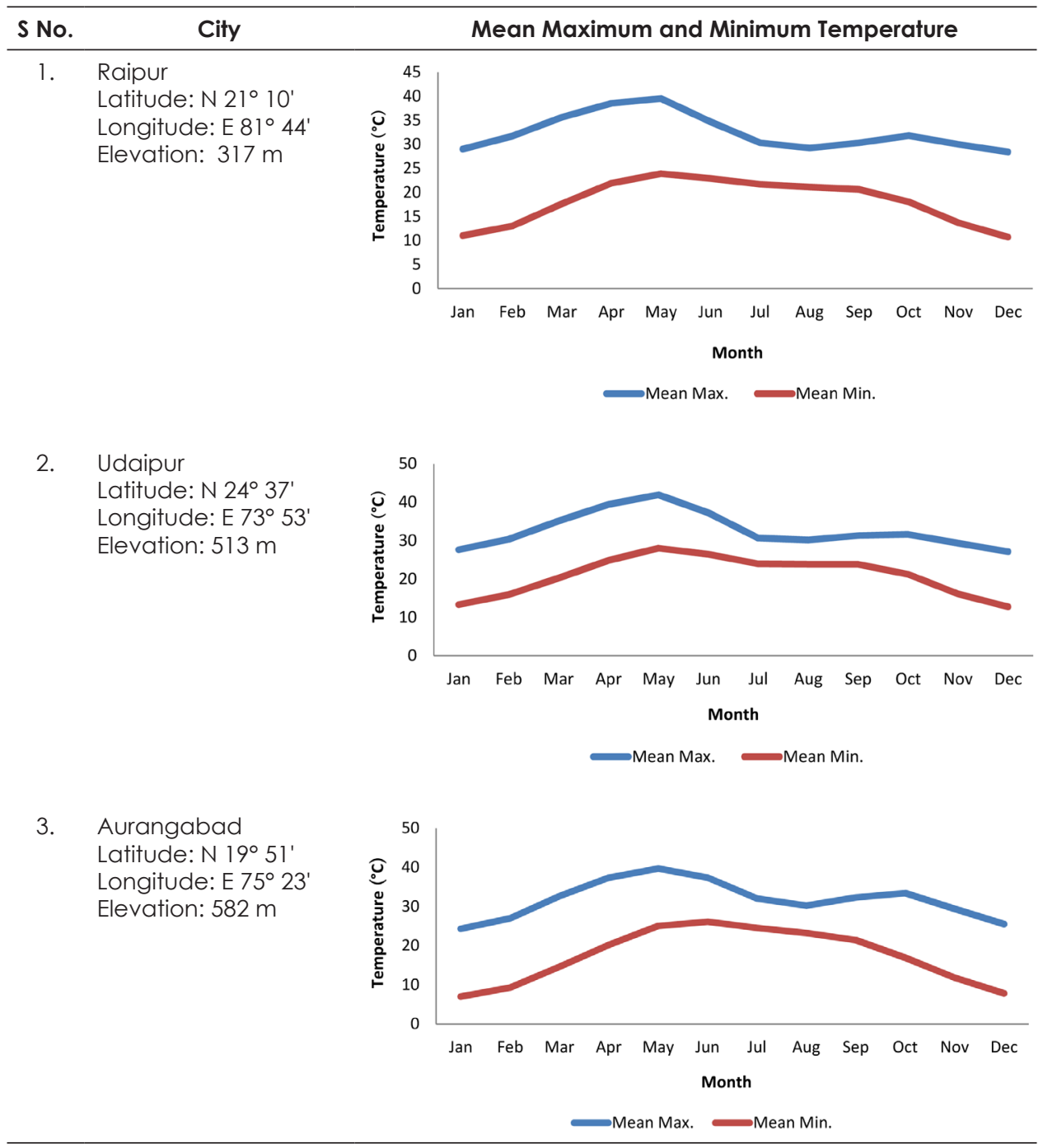

Table 2. Traffic Details of The Three Analysed Airports

\begin{tabular}{lccc}
\hline \multicolumn{1}{c}{ Airport } & Passengers & Aircraft Movements & Cargo (In Tonnes) \\
\hline Raipur & 925504 & 8425 & 3951 \\
Udaipur & 457841 & 5647 & - \\
Aurangabad & 426855 & 4141 & 1250 \\
\hline
\end{tabular}


An analysis of the building energy bills was done on monthly basis for last 2-3 years. Besides that, the peak load and occupancy data, on monthly basis, for last 2-3 years was collected. In addition, the energy system maintenance expenses on monthly basis for the last 2-3 years were reviewed. The objective of this study is to estimate the opportunities for peak load savings and to study energy consumption trends for developing multifaceted energy efficiency projects in the terminal building. The analysis of this collected data was used for identification of variables affecting energy consumption.

To study the electrical supply and distribution system the data was collected after 24 hours monitoring of building load trends with 2 minute intervals. The objective of studying this data is to reduce the transformer loss by optimum transformer loading and to reduce the distribution losses if any. The analysis of this data was done by calculation of load versus efficiency of the transformers.

The lighting system was studied after collecting the inventory of lighting fixtures (type and number of fixtures). Room wise lux measurement (day time and evening time) was taken and the type of activity was reviewed. The hours of operation of the lighting fixtures were studied to measure power consumption for lighting. The objective of this lighting analysis was to identify the potential for energy saving by application of energy efficient lighting fixtures and the optimization of existing systems and at the same time providing optimum comfort level lighting to the occupants of the building. The collected data was analysed through: 1) performance assessment of lighting system (ILER assessment); 2) projected lighting consumption for the year in $\mathrm{kWh}$; 3) recommendation for number of actual light fixtures required after fulfilling the specified lux for each area as per site conditions; and 4) identification of areas where new techniques such as occupancy sensors/ master controls can be taken up.

For the air conditioning system analysis, an inventory of air conditioners (type, numbers and age) was done. The tons delivered under the existing weather conditions (air flow, inside air temperature and humidity, and outside air temperature and humidity) were measured. The air conditioner control operations were reviewed to ascertain whether it is time cycle based control or temperature controlled. The hours of operation and the air conditioned floor area of the terminal building were also accounted for. The objective of this study was to identify potential energy savings by installing efficient $A / C$ units and optimizing their operations and maintenance, for minimum energy consumption and at the same time providing optimum comfort level to the occupants.

Detailed evaluation of energy performance of equipment was done, with respect to operation efficiencies and comparison of these values with typical industry norms and thereby establishing margins for improvements. Based on this analysis identification of energy conservation opportunities (ENCON) was done.

\section{INTRODUCTION TO THE SELECTED CASE STUDIES}

\section{Raipur Airport}

Swami Vivekananda International Airport, Raipur is the primary airport serving the state of Chhattisgarh, India. In 2006, this airport witnessed an $82 \%$ increase in passenger traffic (the highest in the country for that year). The airport is one of the 35 non-metro airports recently modernized by the AAI. The airfield features one 
2,320 m asphalt runway bearing orientation $06 / 24$ with coordinates of $21^{\circ} 10^{\prime} 52^{\prime \prime}$ $\mathrm{N}$ latitude and $81^{\circ} 44^{\prime} 18.5^{\prime \prime} \mathrm{E}$ longitude. It features two parking aprons, one for the passenger terminal, and the other for the cargo terminal. The passenger terminal apron has stands for up to four single-aisle aircraft such as the Airbus A320 family or Boeing B737 family. The total land area of the airport is 638.38 acres. Figure 3 shows the location of the terminal building in the master plan layout of Raipur Airport. The site area of the airport is $20,900 \mathrm{sqm}$ and the built-up area of the terminal building is 18,500 sqm with the ground floor having a building footprint of 14,000 sqm and the first floor having a building footprint of $4,500 \mathrm{sqm}$. The new terminal building is designed to accommodate 700 passengers, including 200 international passengers. With the increase in passengers is the added pressure on the resources at the airport due to the extensive use of artificial lighting and HVAC systems. The planning team envisioned to globalise the airport terminal, to not only create a world class terminal, but also to direct and integrate the commercial built form into an environmentally sustainable abode. It was inaugurated on 7 November 2012. Figure 4 shows the new integrated terminal building at Raipur Airport.

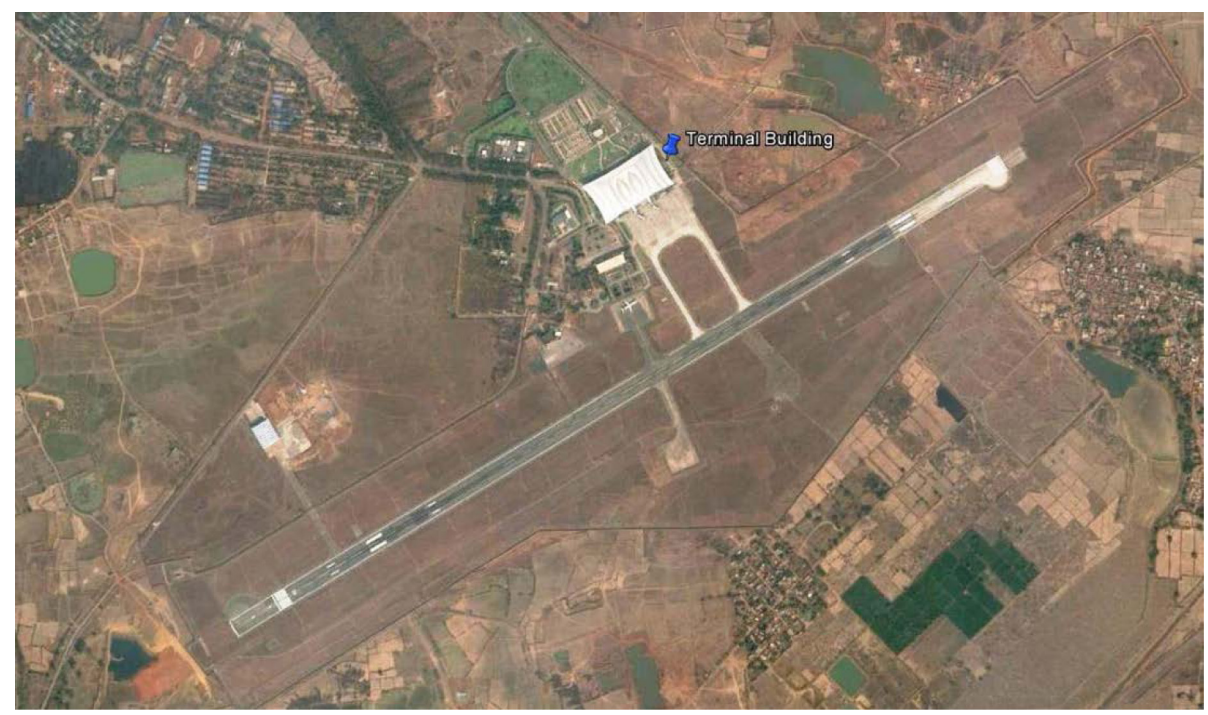

Figure 3. The Location of Terminal Building in The Master Plan Layout of Raipur Airport Source: Google Earth (11/03/2016)

\section{Aurangabad Airport}

Chikkalthana Airport is a public airport located in Aurangabad, Maharashtra, India. The airport opened to regular traffic on 3 March 2009. The airfield features one $2,835 \mathrm{~m}$ asphalt runway bearing orientation 09/27 with coordinates of $19^{\circ} 51^{\prime}$ '52' $\mathrm{N}$ latitude and $75^{\circ} 23^{\prime} 51^{\prime \prime E}$ longitude. It features two parking aprons, one for the passenger terminal and the other for the cargo terminal. The passenger terminal apron has stands for up to four single-aisle aircraft such as the Airbus A320 family or Boeing B737 family. The total land area of the airport is 557.55 acres. The total built up area is 23220 sqm. Figure 5 shows the location of the terminal building in 
the master plan layout of Aurangabad Airport. The airport terminal building area is 20,500 sqm and out of this 19,000 sqm is conditioned area. In addition to the above, they have other main buildings i.e. ATS building and fire station building having around 2,720 sqm covered area of which around $60 \%$ area is air-conditioned. It is an integrated (domestic and international) two-storey, glass-and-steel terminal building (with four entry and exit points) and a 30-m high technical complex (with a floor area of $620 \mathrm{~m}^{2}$ ) and costing approximately Rs 1 billion. It is a north facing

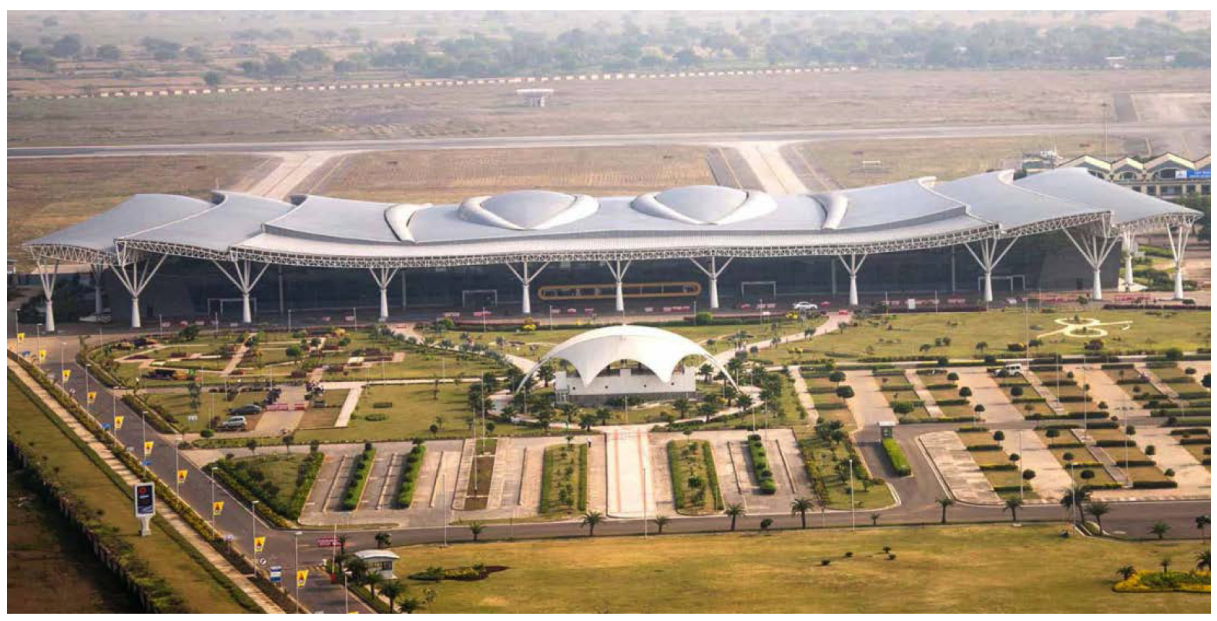

Figure 4. The New Integrated Terminal Building, Raipur Airport Source: https://www.nbmcw.com/articles/architects-project-watch/32029-the-raipurairport.html (16 May 2016)

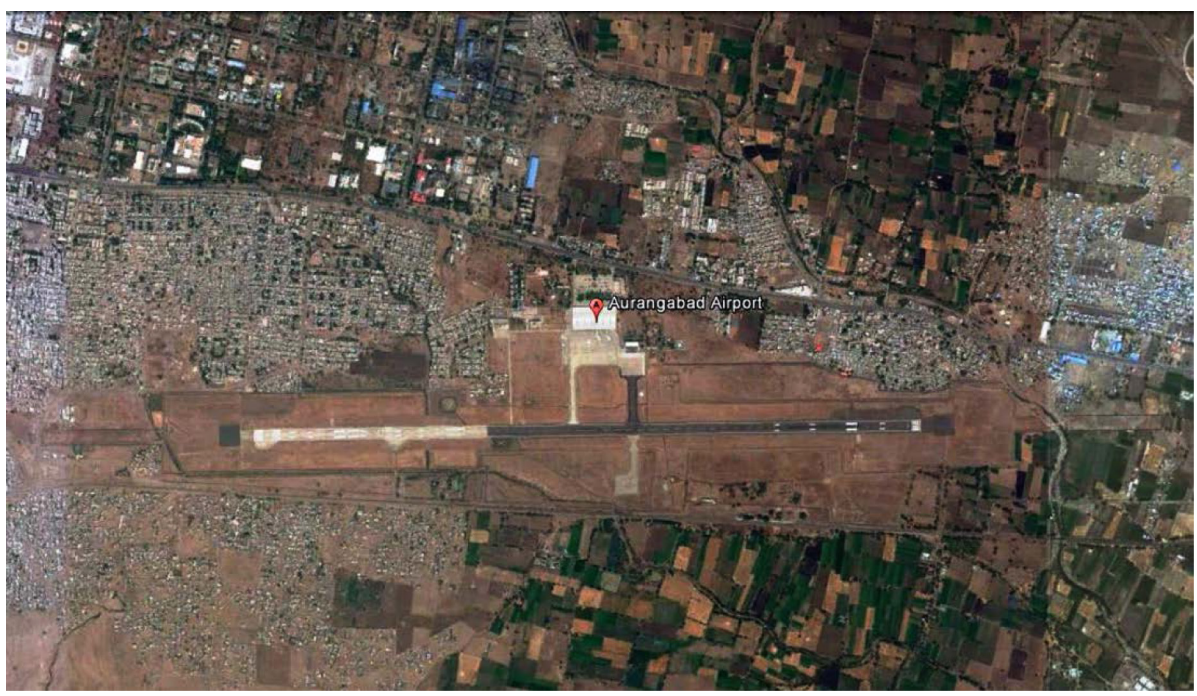

Figure 5. The Location of Terminal Building in The Master Plan Layout of Aurangabad Airport

Source: Google Earth (03/24/2017) 
building and having double glazing glass of $6 \mathrm{~mm}-8 \mathrm{~mm}-6 \mathrm{~mm}(6 \mathrm{~mm}$ glass thickness with $8 \mathrm{~mm}$ air gap) at north and south side whereas east and west side has $12 \mathrm{~mm}$ thick glass with insulated film. Its roof structure is made of aluminium sheet-insulation then metal sheet. On the roof around 7 nos. of transparent sheet made of fibre reinforced plastic (FRP) hoods are provided for sun light facility at the terminal. It is designed to cater for 800 peak hour passengers. Figure 6 shows the terminal building while Figure 7 shows the interiors of the PTB at Aurangabad Airport.

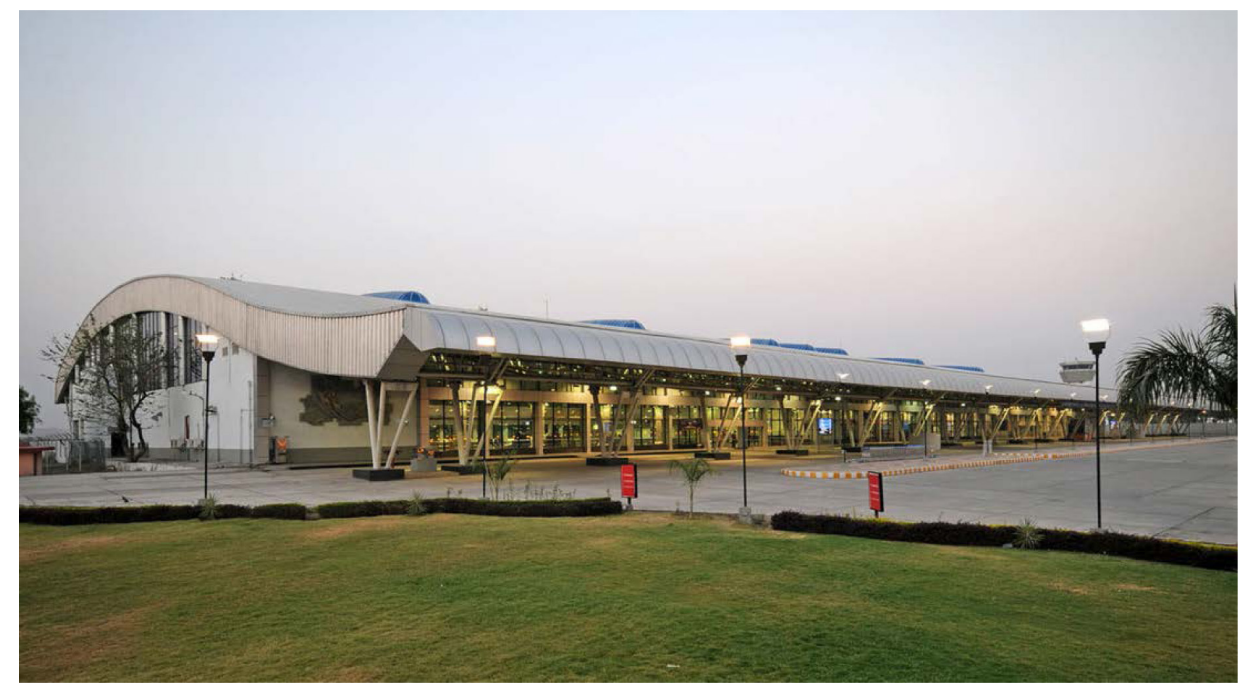

Figure 6. The Terminal Building at Aurangabad Airport Source: https://en.wikipedia.org/wiki/Aurangabad_Airport\#/media/File:Aurangabad_ Airport_New_Terminal_Building.jpg 21 March 2010 (16 May 2016)

\section{Udaipur Airport}

Maharana Pratap International Airport or Udaipur Airport is a commercial domestic airport at Udaipur, Rajasthan, India. It is situated $22 \mathrm{~km}$ east of Udaipur. The newly built Udaipur Airport, which became functional in 2008, is a state of the art modern airport with passenger friendly facilities. About 6,000 aircraft movements take place in a year at the airport. Figure 8 shows the location of Udaipur Airport. The airfield features one 2,281 $\mathrm{m}$ asphalt runway with width of $45 \mathrm{~m}$ bearing orientation $08 / 26$ with coordinates of $24^{\circ} 37^{\prime} 04^{\prime \prime} \mathrm{N}$ latitude and $73^{\circ} 53^{\prime} 46^{\prime \prime} \mathrm{E}$ longitude. Its 250 by $150 \mathrm{~m}$ apron provides parking space for three Boeing 737s or Airbus A320 aircraft at a time. The total land area of the airport is 504 acres. The terminal building of glass and steel structure is centrally air-conditioned 3-storeyed building having built-up area of $12,000 \mathrm{~m}^{2}$. It is equipped to handle 300 passengers each at departure and arrival with total of 600 passengers. Figure 9 shows the terminal building at Udaipur Airport. The complex also includes operational and technical blocks and air traffic control (ATC) tower besides residential colony and buildings for utilities like powerhouse pump house and central AC plant room. The operational block is a threestoreyed glass glad structure having an area of $3,100 \mathrm{~m}^{2}$. The technical block is also of 3,100 $\mathrm{m}^{2}$ area but has masonry walls. The ATC building area is $400 \mathrm{~m}^{2}$, which mainly consists of a glass dome on top. 


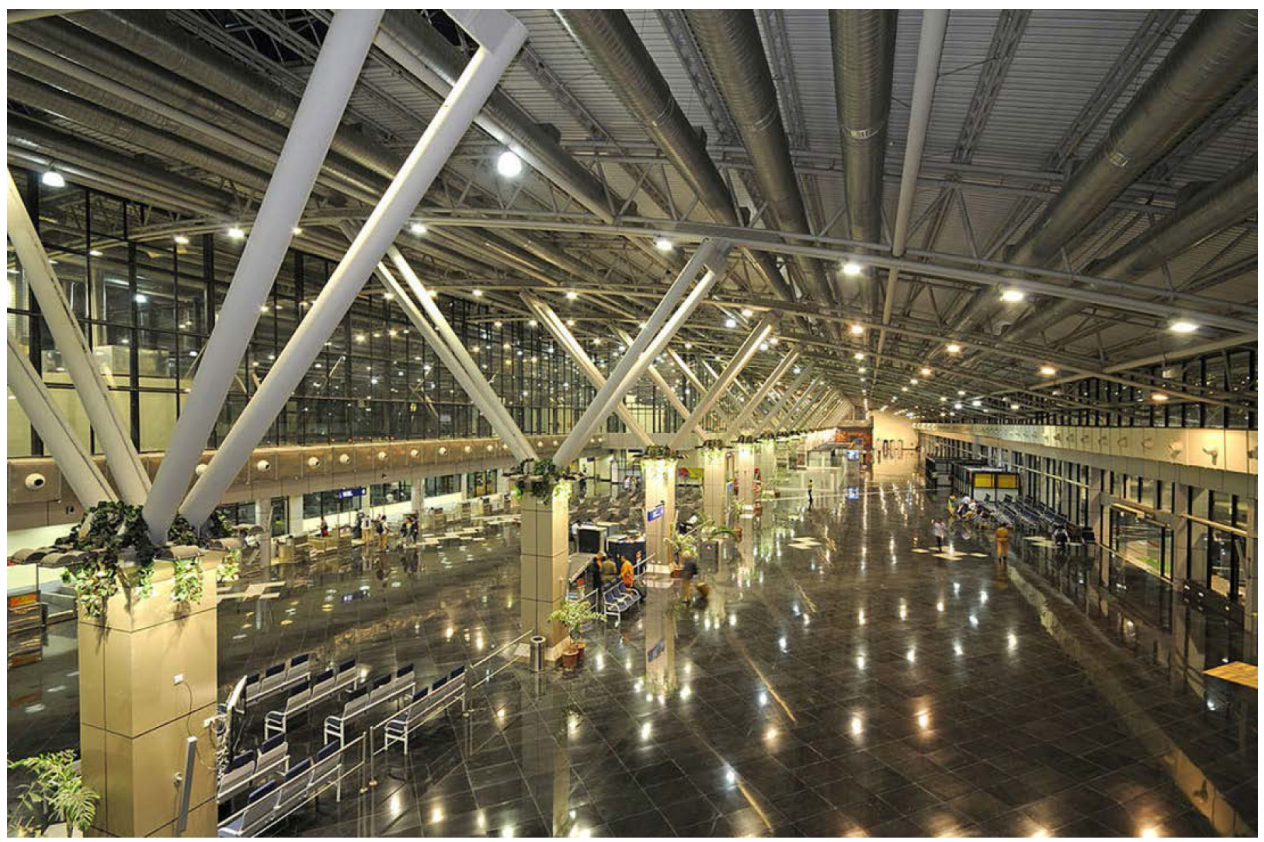

Figure 7. The Interiors of the Passenger Terminal Building at Aurangabad Airport Source: https://en.wikipedia.org/wiki/Aurangabad_Airport\#/media/File:Inside_New_Terminal_ Building.jpg. 20 March 2010 (16 May 2016)

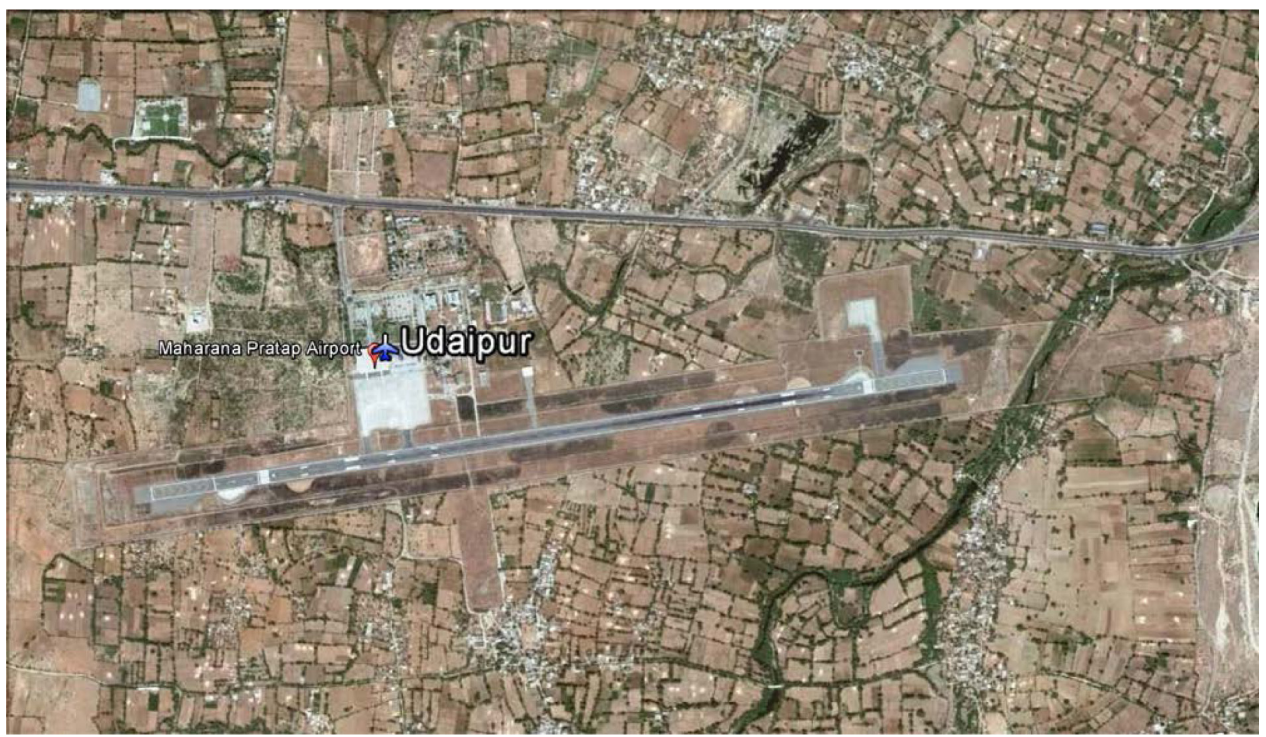

Figure 8. The Location of Udaipur Airport Source: Google Earth (02/07/2017) 


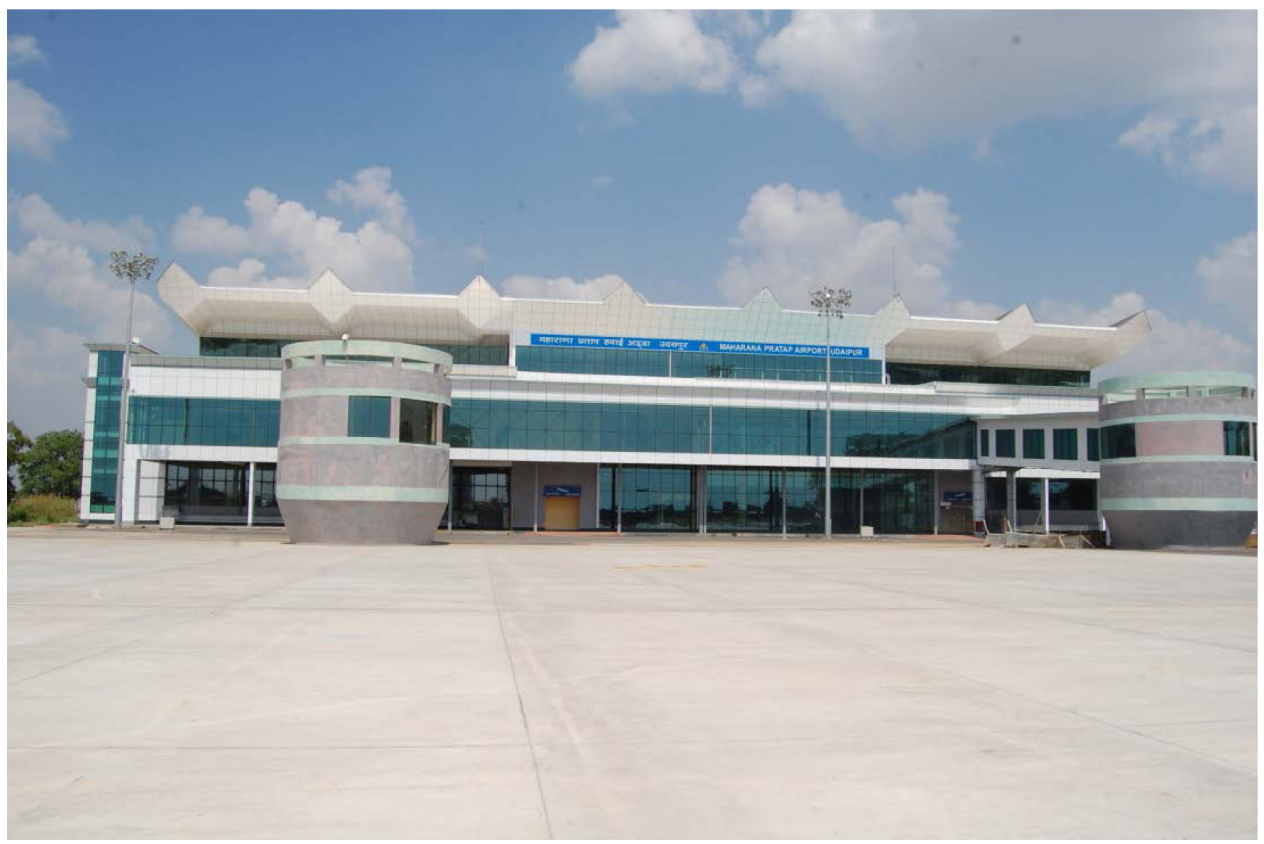

Figure 9. The Terminal Building at Udaipur Airport

\section{POWER AND ENERGY CHARACTERISTICS OF THE THREE AUDITED AIRPORTS}

The annual total energy consumption at Udaipur Airport is $35,74,140 \mathrm{kWh}$, while Raipur Airport has a total energy consumption of 44,53,739 kWh and Aurangabad Airport has a total energy consumption of $29,41,950 \mathrm{kWh}$.

Energy consumption per passenger is also a useful indicator for the average energy performance of the facilities. Using data of the passenger traffic from the three airports over a 1 year period it was found that the total energy consumption averaged $4.35 \mathrm{kWh}$ per passenger at Raipur Airport, $8.05 \mathrm{kWh}$ per passenger at Aurangabad Airport, and $7.55 \mathrm{kWh}$ per passenger at Udaipur Airport. The average carbon emission per passenger was 4.35 at Aurangabad Airport, 3.86 at Udaipur Airport, and 2.18 at Raipur Airport. Carbon emission is calculated by assuming that $0.5 \mathrm{~kg}$ is emitted per energy consumed.

Based on the energy consumption pattern, the average per unit cost to the Aurangabad airport is around Rs. 12.84 per unit (annual avg. 2014-2015), Rs. 6.86 per unit for Udaipur Airport, and Rs. 6.38 per unit for Raipur Airport. Table 3 shows the overview of the characteristics and actual energy consumption of the three Indian airports studied.

The average electrical energy consumption is $240.74 \mathrm{kWhel} / \mathrm{m}^{2}$ at Raipur Airport, $200 \mathrm{kWhel} / \mathrm{m}^{2}$ at Aurangabad Airport, and $341.67 \mathrm{kWhel} / \mathrm{m}^{2}$ at Udaipur Airport. The floor area used for the calculations is the total area of the airport terminal, which is 18,500 sqm for Raipur Airport, 20,500 sqm for Aurangabad Airport, and 12,000 sqm for Udaipur Airport. 

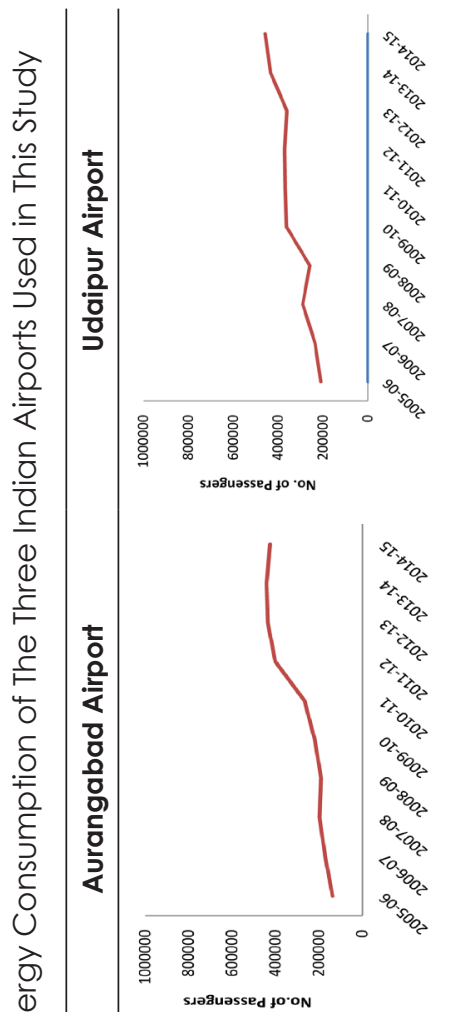

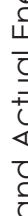

$\frac{0}{0}$
$\frac{y}{0}$
0
0
0
0
$\frac{0}{0}$
$\frac{1}{0}$

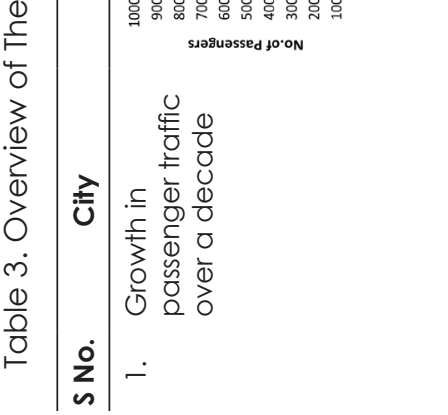

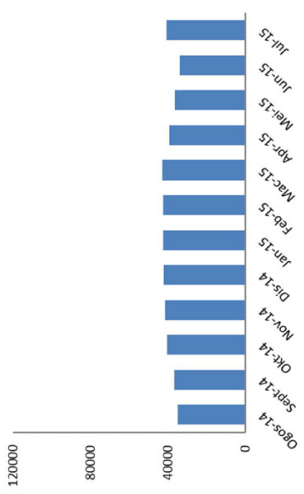
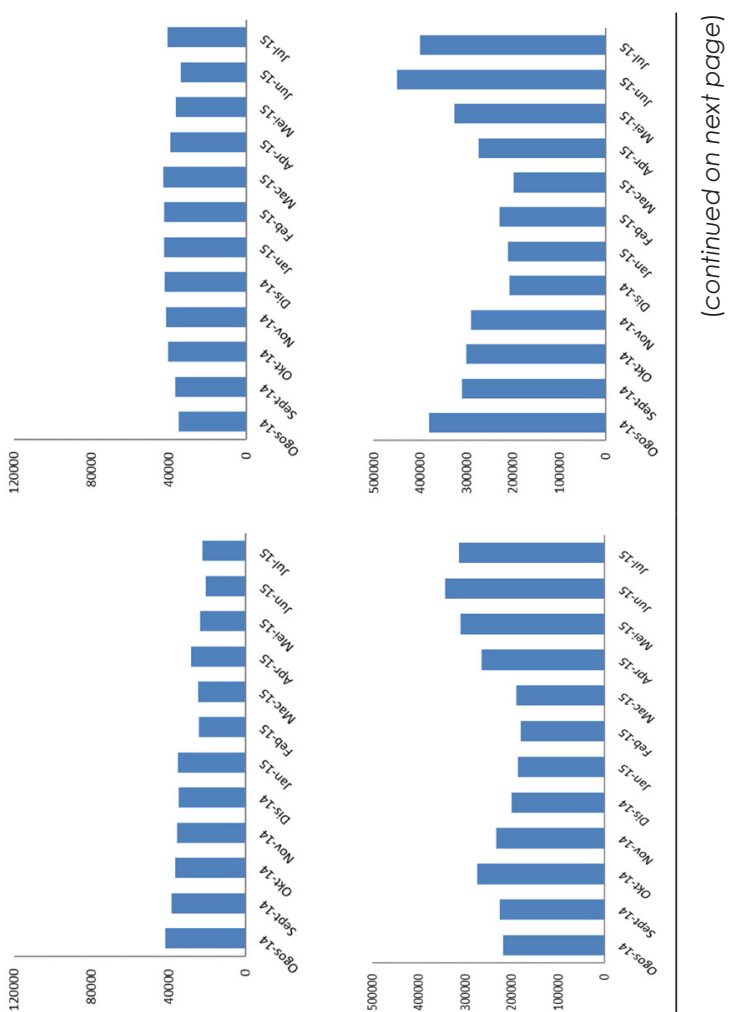
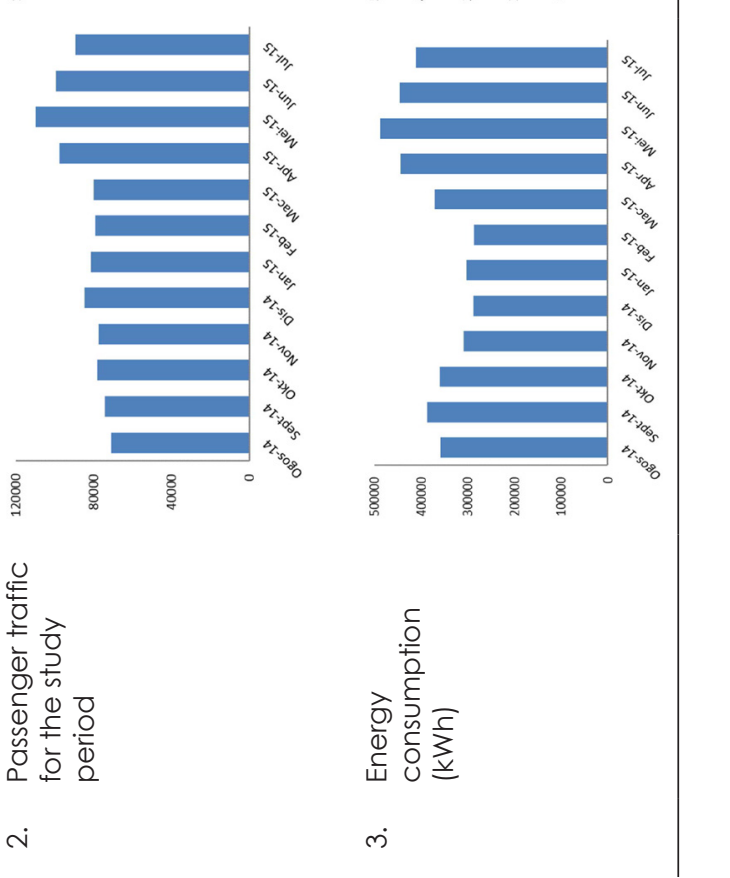

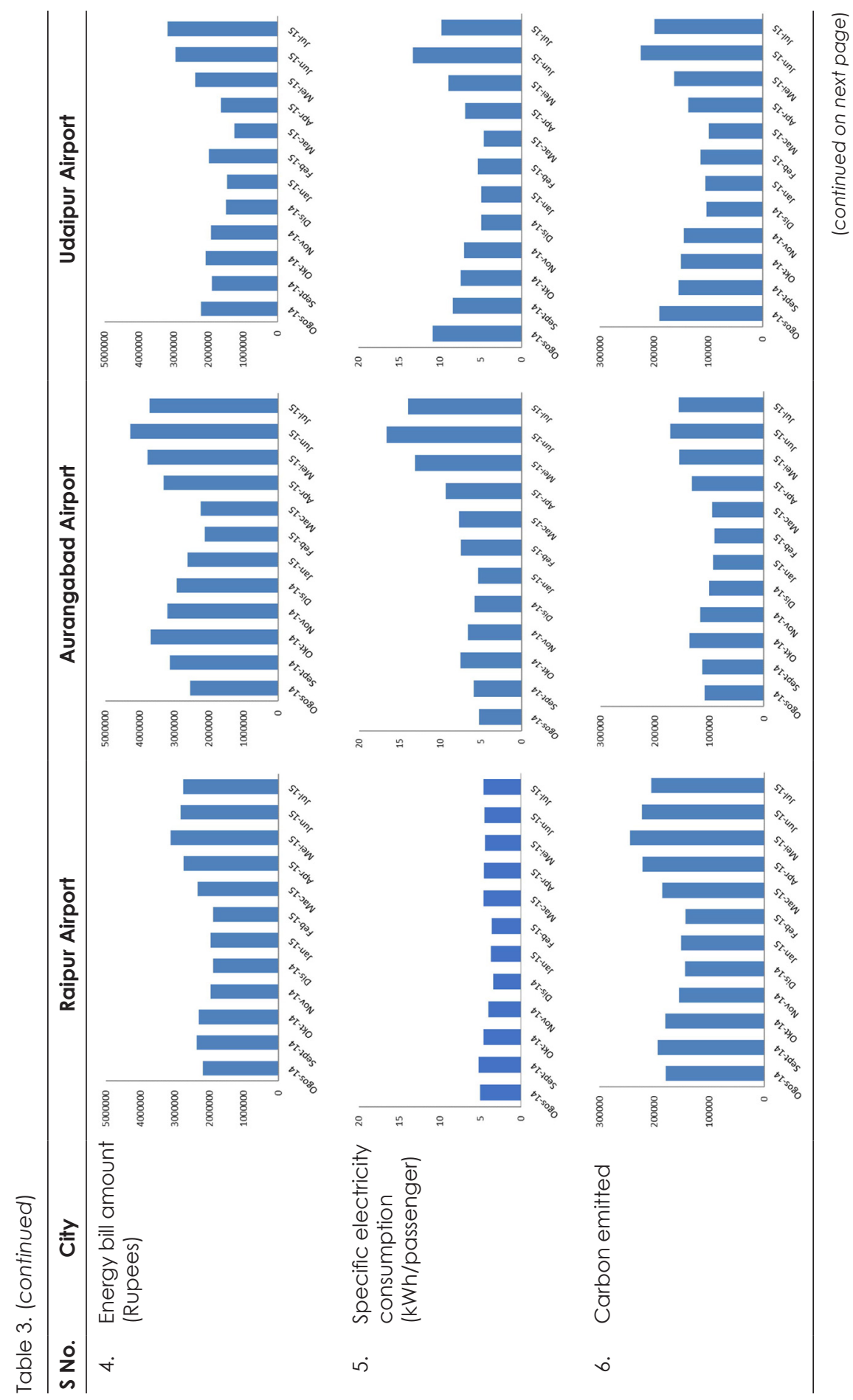

PENERBIT UNIVERSITI SAINS MALAYSIA/111 

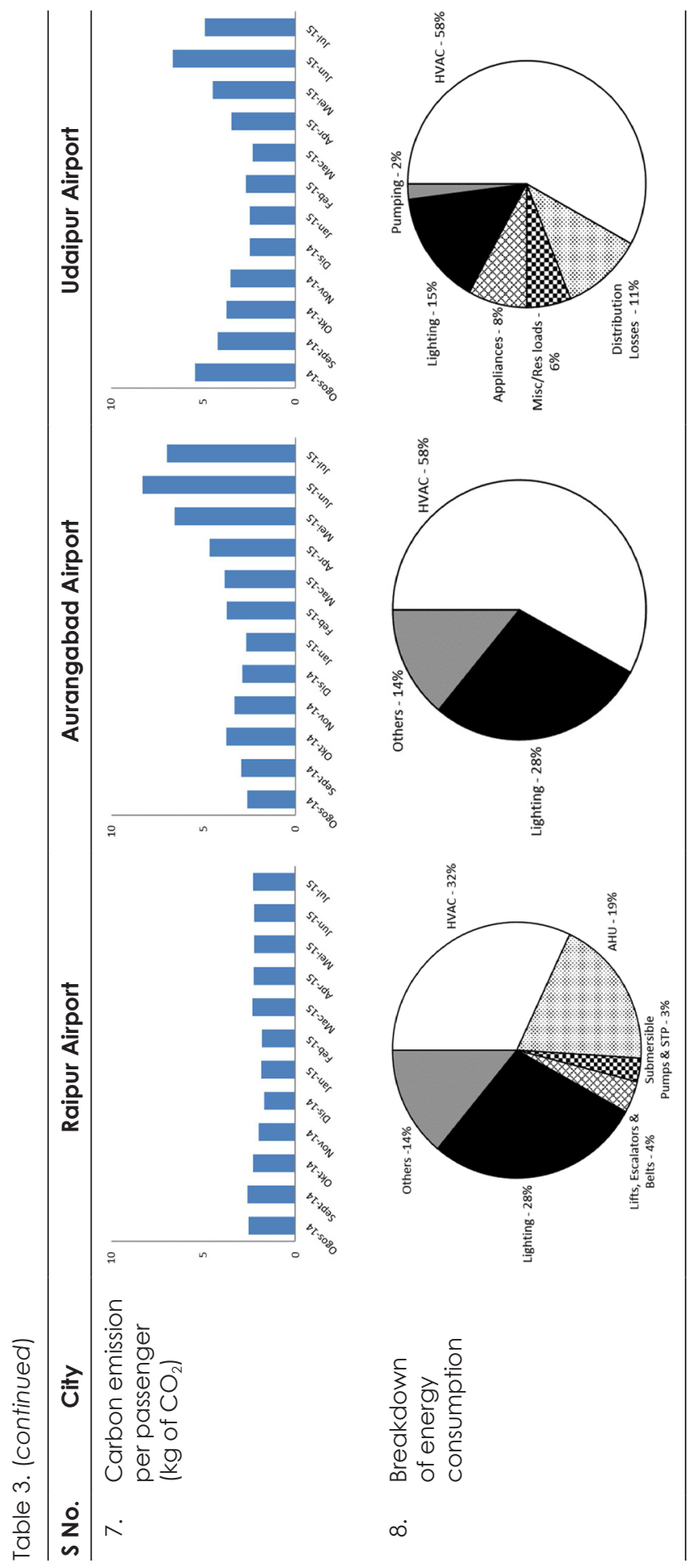


\section{Raipur Airport}

The following observations were made after analysis of collected data:

After the analysis of the bills it has been observed that the energy consumption for one year (August 2014 to July 2015) is 4.45 Gigawatt with the maximum consumption in the month of May. The average monthly energy purchase is 0.685 Gigawatt kWh, charges were Rs. 4.1/kWh up to June 2015; after that i.e. from July 2015 onwards, energy charges were Rs. 5.46/kWh during on-peak hours, Rs. 3.57/ $\mathrm{kWh}$ during off peak hours, and Rs. 4.2/kWh during normal hours. Energy charges paid by AAI Raipur is 28.3 million for one year that is from August 2014 to July 2015. Maximum energy consumption and maximum energy demand is in the month of May 2015 and June 2015.

The operating power factor (PF) at the Raipur Airport is near to unity. AAI is getting incentive if PF is higher than 0.95 and if power factor is lower than 0.95 then surcharge has to be paid (power factor is a measure of the electrical systems efficiency, which can be in the range of 0 to 11 . The loading of the transformers at the airport is not optimum. In some of the rooms at the airport the height of the fixtures is on the higher side (i.e. 7 meters). It is suggested to lower the fixtures height to increase lumens with decreasing number of lamps.

In most of the offices and indoor areas there are 40W fluorescent tubelights (FTL), which needs to be replaced with retrofit light emitting diode (LED). Cooling tower (CT) range and effectiveness is on the lower side. It was observed that the airport operates two CTs with one chiller. Chiller statistical process control (SPC) is on the higher side. SPC is a method of quality control that uses statistical methods. SPC is applied to monitor and control a process. Monitoring and controlling the process ensures that it operates at its full potential.

Pumps efficiency is on the lower side. Ton of refrigeration (TR) generation of most of the air handling unit (AHU) is on the lower side. The departure side air is supplied to all AHU filters via treated fresh air units (TFA). The TFA takes air from the atmosphere and supplies to all AHU filters via chilled water coils. All walls of the water coils need to be insulated. Therefore, where excesses were observed, accordingly measures will have to be taken in those areas to curtail the energy consumption as well as the cost incurred.

After an analysis of the energy audit, certain energy saving recommendations that can be given are presented in Table 4. It is strongly recommended to replace T12 light with LED $18 \mathrm{~W}$; by doing so there is saving of Rs 3.18/lakh per year. The energy saved is $48,866 \mathrm{kWh}$ per year with a payback period of 2.46 years.

Separate lighting and install lighting energy saver at lighting feeder. By installing lighting energy saver there is saving of Rs 19.21 lakhs per year. The energy saved is 29,5481 kWh per year with a payback period of 11 months. Chiller SPC is on the higher side. Differential pressure and approach of condenser as well as evaporator is on the higher side. Evaporator and condenser tubes needs to be cleaned. After maintenance of chiller there is saving of Rs $5.90 /$ lakh per year. The energy saved is $90,720 \mathrm{kWh}$ per year with immediate payback period.

Pumps (primary, secondary, and condenser water) efficiency is very low. Maintenance of pumps needs to be done, which will bring a saving of Rs 2.29 /lakh per year. The energy saved is $35,179 \mathrm{kWh}$ per year with immediate payback period. Optimization of CT as per HVAC load needs to be done. It was observed that two CTs are operated with one chiller. It is recommended to operate one CT with one chiller. After switching of CT there is saving of Rs 3.11/lakh per year. The energy saved is $4,7880 \mathrm{kWh}$ per year with immediate payback period. 
Table 4. Energy Saving Recommendations for Raipur Airport

\begin{tabular}{|c|c|c|c|c|c|}
\hline S No. & Saving Measures & $\begin{array}{l}\text { Annual Energy } \\
\text { Saved (kWh) }\end{array}$ & $\begin{array}{l}\text { Amount Saved } \\
\text { (Lakh Rs/USD/yr) }\end{array}$ & $\begin{array}{c}\text { Investment } \\
\text { (Lakh Rs/USD) }\end{array}$ & $\begin{array}{c}\text { Payback } \\
\text { Period (Years) }\end{array}$ \\
\hline 1 & $\begin{array}{l}\text { Install energy saver } \\
\text { lighting }\end{array}$ & 295,481 & $19.21 / 28,095$ & $17.5 / 25,594$ & 0.91 \\
\hline 2 & $\begin{array}{l}\text { Replace } 40 W \text { FTL } \\
\text { by } 18 W \text { LED }\end{array}$ & 48,866 & $3.2 / 4,680$ & $7.8 / 11,408$ & 2.5 \\
\hline 3 & $\begin{array}{l}\text { Overhauling } \\
\text { chillers and AHU }\end{array}$ & 90,720 & $5.2 / 7,605$ & Minimum & Immediate \\
\hline 4 & $\begin{array}{l}\text { Optimise cooling } \\
\text { towers }\end{array}$ & 47,880 & $3.1 / 4,548$ & Minimum & Immediate \\
\hline 5 & $\begin{array}{l}\text { Maintenance of } \\
\text { pumps }\end{array}$ & 35,179 & $2.29 / 3,350$ & Minimum & Immediate \\
\hline & Total & 518,126 & $33.01 / 48,278$ & $25.30 / 37,000$ & 0.77 \\
\hline
\end{tabular}

\section{Aurangabad Airport}

The following observations were made after analysis of collected data:

After the analysis of the bills it has been observed that the energy consumption for one year (August 2014 to July 2015) is 2.94 Gigawatt with the maximum consumption in the month of June. The average monthly energy purchase is 0.452 Gigawatt. Energy charges paid by AAl for Aurangabad Airport is 37.6 million for one year that is from August 2014 to July 2015.

The annual average power factor is maintained around 0.99 as per electricity bills. Aurangabad Airport is regularly getting PF rebate every month but there is a scope of getting further rebate on power factor i.e. by maintaining PF around 0.995 and above, Rs. 7.84 lakhs can be saved. During audit, all the capacitors were checked for their performance and some of the capacitors needed immediate attention. The airport has 1,500 KVA contracted demand. As per analysis, it is found that it has never crossed 1,253 KVA and minimum it has touched $899 \mathrm{KVA}$. If there is no future load expansion plan, then $150 \mathrm{KVA}$ can be easily surrendered that will give a monetary saving of Rs. 3.42 lakhs per year.

The analysis of the lighting fixtures was done by measuring lux levels and room dimensions by the project team and calculated lux/watt/sqm and ILER. The analysis suggests that there is potential to save energy around 847,143 units worth of Rs 50,16,631 by replacing existing fixtures like FTLs, street lights, CFLs, and T-5 lighting with LED energy efficient lighting system.

The chiller performance was analysed and actual TR generation is calculated for all the working machines. The outlet chilled water temperature is delivered around $14^{\circ} \mathrm{C}-15^{\circ} \mathrm{C}$ instead of the expected $8^{\circ} \mathrm{C}-10^{\circ} \mathrm{C}$. It needs attention. The CT performance also needs immediate attention as it is poor. The temperature change is coming around $2^{\circ} \mathrm{C}$ against the $4^{\circ} \mathrm{C}$ and most of the fill material is choked. Besides that, the water is falling unequally i.e. at some places there is no water and at some places a lot of water is falling. The location of CT is very near to transformers due to which transformer is getting moisture frequently due to evaporated water at CT. This needs immediate attention. 
The overall specific energy consumption (KW/TR) is calculated i.e. 1.23. It includes pumps and CT. The AC's specific energy consumption (SEC) should be around $1.0 \mathrm{KW} / \mathrm{TR}$. The AC plant is designed for the entire terminal and it is not used fully as the international flights are not operating presently so that area of the terminal building (TB) remains underutilized; nonetheless, it has to be cooled also due to design constraints. However, some of the AHUs need to be optimized, which will help to save around 127,200 units/year, which is worth Rs. 13.29 lakhs.

For Aurangabad Airport, the details of scope of anticipated savings including recommendations, saving in units, saving in rupees, approximate investment, and payback period is mentioned in Table 5.

Table 5. Energy Saving Recommendations for Aurangabad Airport

\begin{tabular}{cccccc}
\hline S No. & Saving Measures & $\begin{array}{c}\text { Annual Energy } \\
\text { Saved (kWh) }\end{array}$ & $\begin{array}{c}\text { Amount Saved } \\
\text { (Lakh Rs/USD/yr) }\end{array}$ & $\begin{array}{c}\text { Investment } \\
\text { (Lakh Rs/USD) }\end{array}$ & $\begin{array}{c}\text { Payback } \\
\text { Period (Years) }\end{array}$ \\
\hline 1 & $\begin{array}{l}\text { LED lights and auto } \\
\text { Controls }\end{array}$ & $608,070.92$ & $63.5 / 92,870$ & $82.54 / 120,716$ & 1.3 \\
2 & $\begin{array}{l}\text { Overhauling chillers } \\
\text { and AHU }\end{array}$ & 127,200 & $13.29 / 19,437$ & 0 & 0.00 \\
$3 \quad \begin{array}{l}\text { Optimising cooling } \\
\text { towers }\end{array}$ & 12,744 & $1.33 / 1,945$ & $1.60 / 2,340$ & 1.37 \\
$4 \quad \begin{array}{l}\text { Maintenance of } \\
\text { pumps }\end{array}$ & 9,504 & $0.99 / 1,448$ & 0 & Immediate \\
5 & $\begin{array}{l}\text { Distributed PF } \\
\text { correction at major } \\
\text { load centres }\end{array}$ & 15,330 & $1.60 / 2,340$ & $1.75 / 2,560$ & 1.23 \\
\hline & & & & $145.75 / 213,162$ & \\
\hline
\end{tabular}

\section{Udaipur Airport}

For Udaipur Airport, the following observations were made after analysis of data:

After analysis of the bills it has been observed that the energy consumption for one year (August 2014 to July 2015) is 3.57 Gigawatt with the maximum consumption in the month of June. The average monthly energy purchase is 0.549 Gigawatt. HVAC is the single biggest energy consuming system followed by lighting. As air conditioning is the major consumer of energy, the weather severity and its duration are the main variables impacting energy baseline. It is seen that the consumption during December to April is lowest while it is highest during the months of May, Jun, and July when it crosses the figure of 4 lakh $\mathrm{KWh}$. The consumption in the months of August, September, October, and November is moderate reflecting impact of weather. Energy charges paid by AAI for Udaipur Airport is 24.4 million for one year that is from August 2014 to July 2015.

For Udaipur Airport, after the analysis of data, following energy efficiency measures have been identified as presented in Table 6. The demand remained above the minimum billing demand (MBD) only in three months but it remained below MBD during nine months. It is indicative of saving opportunity by reduction in the contracted demand in conjunction with intelligent load management system (ILMS) for containing demand within $1000 \mathrm{KVA}$. 
Table 6. Energy Saving Recommendations for Udaipur Airport

\begin{tabular}{clcccc}
\hline S No. & Saving Measures & $\begin{array}{c}\text { Annual Energy } \\
\text { Saved (kWh) }\end{array}$ & $\begin{array}{c}\text { Amount Saved } \\
\text { (Lakh Rs/USD/yr) }\end{array}$ & $\begin{array}{c}\text { Investment } \\
\text { (Lakh Rs/USD) }\end{array}$ & $\begin{array}{c}\text { Payback } \\
\text { Period (Years) }\end{array}$ \\
\hline 1 & $\begin{array}{l}\text { LED lights and auto } \\
\text { controls }\end{array}$ & 400,000 & $24.0 / 35,100$ & $65.0 / 95,065$ & 2.70 \\
2 & $\begin{array}{l}\text { Overhauling chillers } \\
3\end{array}$ & 340,000 & $20.40 / 29,836$ & $9.2 / 13,455$ & 0.50 \\
$\begin{array}{l}\text { Overhauling } \\
\text { package plants }\end{array}$ & 30,000 & $1.80 / 2,632$ & $2.0 / 2,925$ & 1.20 \\
4 & $\begin{array}{l}\text { AC energy savers } \\
\text { for ACs }\end{array}$ & 30,000 & $1.80 / 2,632$ & $3.8 / 5,622$ & 2.10 \\
5 & $\begin{array}{l}\text { Maintenance of } \\
\text { pumps }\end{array}$ & 80,000 & $4.80 / 7,020$ & $20.0 / 29,250$ & 4.10 \\
6 & $\begin{array}{l}\text { Distributed PF } \\
\text { correction at major } \\
\text { load centres }\end{array}$ & 30,000 & $1.80 / 2,632$ & $2.0 / 2,925$ & 1.20 \\
\hline & & & & 2.00 \\
\hline
\end{tabular}

The occupancy at airport depends mainly on the flights being operated. It is, however, noteworthy that a minor change in number of flights may not lead to a significant variation in the energy baseline as the terminal remains operative since early morning to late evening hours whether the flights are reduced or increased.

As one of the transformers was defective, thus, transformer efficiency and losses could not be calculated precisely. As transformers have highest efficiency (lowest losses) at about 50\% loading and the present max loading of the transformers is also around $50 \%$, it can be inferred that the transformers are operating near the rated efficiencies of $97 \%$.

The losses in the electrical network are of the order of $8 \%$ as per the data available even though precise evaluation of the distribution losses in the electrical network is not possible unless a long duration study of loading of various subnetworks is carried out. The surveys of load cum power quality with power analyser at various load centres indicates that the PF is low at many places resulting in flow of higher currents and consequential higher distribution losses. Thus, a distributed PF correction can yield significant reduction in energy losses in the distribution system. The harmonics are very high at some places at the airport, which call for mitigation action. Though the energy losses caused by these harmonics may not be significant, the functional performance of sensitive equipment may be adversely affected by harmonics and therefore, there is need for mitigation action.

In the interior lighting system, there is still scope for improving load efficacy though ILER (installed load efficacy ratio) is above 0.75 for most spaces. Replacement of existing lights with LED lights is the major saving opportunity followed by scheduling and dimming. Additional savings of at least $15 \%$ can be achieved by automatic scheduling of on-off controls and dimming. Significant energy savings of at least $30 \%$ can be expected by overhauling of chiller controls.

All the values of $\mathrm{KW} / \mathrm{TR}$ metric for air conditioners are on the higher side indicative of poor efficiency. Thus, there is scope for replacement/retrofit to improve performance of room ACs. 


\section{CONCLUSIONS}

All available information that was reviewed in the previous sections was used to tailor the proposed interventions and suggest potential energy conservation scenarios at the three audited airports.

The most effective measures, of the ones that were proposed and assessed, along with the corresponding results are summarized in the tables. Information on the actual flight schedules and passenger loads were used in order to properly configure the operating schedules of the HVAC systems, depending on the anticipated loads.

Supplementary calculations were also performed. For example, in relation to indoor and outdoor artificial lighting, using information from the audits on the number and type of installed lamps and fixtures it was possible to check compliance with desirable levels, specify the number of excessive lights and estimate savings from a reduced number of lighting fixtures, use different operating schedules. A lower installed lighting intensity also reduces internal heat gains.

Following independent variables are identified to be affecting the annual consumption of energy in the facilities:

1. Weather

2. Occupancy

3. Equipment/appliances

4. Operating hours

A change in any of the above variables can lead to a change in the energy baseline. After analysing the data at these airports some energy saving tips that could be implemented at these airports are:

\section{Lighting}

1. Turning off lights when not needed. For example, turning off fluorescent lights saves energy, extends overall lamp life, and reduces replacement costs.

2. Reducing or replacing inefficient, outdated or excessive lighting within the building.

3. When replacing old lighting equipment, evaluating new technologies that may need fewer fixtures and/or fewer lamps within existing fixtures.

4. Ensuring that light levels remain at adequate levels before changing the technology and/or reducing number of lamps.

5. Where practical, replacing incandescent lamps with compact fluorescent lamps (CFLs). Ensuring installation of compatible dimming technology if CFLs are used along with a dimming system.

6. Replacing incandescent "EXIT" signs with LED signs. LEDs use about one-tenth the wattage and last 50 times longer than incandescent lamp signs.

7. Installing lighting occupancy sensors that automatically turn lights on or off, depending on occupancy. These sensors work well in areas at the airport that are not occupied continuously.

8. Taking advantage of natural daylight; turning off or dimming electric lighting when adequate sunlight is available to illuminate interior spaces.

9. Ensuring outdoor lighting is turned off during daytime. 


\section{Heating and Cooling}

1. Establishing a preventative maintenance program for the heating, ventilation, and air conditioning (HVAC) equipment and systems. Ensuring that these are done regularly:

(a) Changing or cleaning all air filters, preferably every month.

(b) Cleaning all heat exchanger surfaces, water and refrigerant coils, condensers, and evaporators.

(c) Repairing leaks in piping, air ducts, coils, fittings, and at the unit(s).

(d) Replacing defective equipment insulation, ducting, and piping.

2. When old motors fail, replacing them with premium efficiency motors that operate at a lower annual cost. Ensuring that the proper sized motor for the application is specified. Installing variable speed drives (VSDs) on large motor loads, where appropriate, to further reduce energy usage.

3. Using outside air- and water-side economizers for cooling when outside air temperatures and conditions permit.

4. In facilities with older chiller, replacing them with new, energy-efficient units that operate at or below 60 kilowatts per ton.

\section{Temperature Control}

1. Adjusting thermostats higher when cooling and lower when heating an occupied building or unoccupied areas within a building during non-operational hours.

2. During summer months, adjusting the thermostat setting up one degree typically can save $2 \%-3 \%$ on cooling costs.

3. Installing locking devices on thermostats to maintain desired temperature settings.

4. Installing programmable thermostats that automatically adjust temperature settings based on the time of day and day of the week. If there are multiple HVAC units, set thermostats to return to the occupied temperature a half an hour apart.

The paper tries to emphasise that before getting down into specific upgrades, the first step towards upgrading an existing property should be to understand its current status in order to establish the airport system baseline. Energy audit is the one of the key to a systematic approach for decision-making in the area of energy management. It quantifies energy usage according to its discrete functions. Although many airports include the audit schedules as a part of their certification renewals and approvals, self-audits by the technical experts frequently help in understanding and analysing the energy minutely in all the aspects. The airport should set the specific performance metrics such as specific energy consumption per passenger, the energy base line or the benchmark should be established for the individual systems within the airport facilities. These measures will go a long way in reducing the energy consumption at Indian airports and thereby being more sustainable in the long run. 


\section{ACKNOWLEDGEMENTS}

The author would like to thank the Airports Authority of India (AAI) for the support in terms of information for the successful completion of this paper. The assistance from the employees at the three audited airports is gratefully acknowledged.

\section{REFERENCES}

American Society of Heating, Refrigerating and Air-Conditioning Engineers (ASHRAE). (2003). Commercial and public buildings, HVAC applications handbook. Atlanta, GA: American Society of Heating, Refrigerating and AirConditioning Engineers Inc., 3.1-3.11.

Ancevic, M. (1997). Intelligent building system for airport. ASHRAE Journal, 39(11): 31-35.

Babu, A.D. (2008). A low energy passenger terminal building for Ahmedabad Airport, India: Building envelope as an environment regulator. Proceedings of the 25th International Conference on Passive and Low Energy Architecture. University College Dublin, Dublin, 22-24 October 2008.

Balaras, C.A., Dascalaki, E., Gaglia, A. and Droutsa, K. (2003). Energy conservation potential, HVAC installations and operational issues in Hellenic airports. Energy and Buildings, 35(1 1): $1105-1120$. https://doi.org/10.1016/j.enbuild.2003.09.006

Edwards, B. (2005). New approaches to airport architecture - The modern terminal. London: E \& FN Spon Ltd.

India Brand Equity Foundation (IBEF). (2016). Indian aviation industry. Available at: $\quad$ https://www.ibef.org/archives/detail/b3ZlcnZpZXcmMzcxNTAmNDk5 [Accessed on 24 June 2016].

International Air Transport Association (IATA). (2013). Air passenger market analysis. Available at: https://www.iata.org/whatwedo/Documents/economics/ passenger-analysis-may-2016.pdf [Accessed on 24 June 2016].

Malviya, A. and Shah, F. (2015). Indian aviation industry: Emerging opportunities and challenges. Asian Research Journal of Business Management, 3(2): 85-95.

Manczyk, H. (2000). Energy efficient O\&M for airport. ASHRAE Journal, 42(7): 43-44.

Maximilian, S. (2014). CASCADE: Reducing energy use by airports. Available at: https://ec.europa.eu/digital-single-market/en/news/cascade-reducingenergy-use-airports [Accessed on 24 June 2016].

Upham, P., Maughan, J., Raper, D. and Thomas, C. (2003). Towards sustainable aviation. London: Earthscan Publications. 


\title{
Assessment of Energy Consumption Pattern and Energy Conservation Potential at Indian Airports
}

\author{
Kanika Malik
}

Published online: 24 November 2017

To cite this article: Kanika Malik. (2017). Assessment of energy consumption pattern and energy conservation potential at Indian airports. Journal of Construction in Developing Countries, 22(Supp. 1): 97-119. https://doi.org/10.21315/jcdc2017.22.supp 1.6

To link to this article: https://doi.org/10.21315/jcdc2017.22.suppl.6

\section{ADDENDUM}

With regard to this article, the author has requested to add and acknowledge that this paper is based on the author's PhD research which is being pursued from Department of Architecture at Deenbandhu Chhotu Ram University of Science and Technology, Murthal, Haryana (India). 